Nuntius Antiquus, Belo Horizonte, v. 13, n. 2, p. 97-115, 2017

\title{
A querela entre filosofia e poesia no Protágoras: uma aporia
}

\section{The Quarrel Between Philosophy and Poetry in Protagoras: An Aporia}

\section{Luiz Paulo Rouanet}

Departamento de Filosofia e Métodos

Universidade Federal de São João Del Rei, São João Del Rei, Minas Gerais / Brasil luizrouanet@terra.com.br

Resumo: No Protágoras, há uma passagem intrigante. Depois de pedir a Protágoras para evitar longos discursos (334d), por supostamente ter curta memória, Sócrates responde ao sofista em um longo discurso sobre um poema de Simônides, do qual Protágoras citara duas sentenças. Desse modo, Sócrates se revela não só possuidor de excelente memória, uma vez que apresenta várias outras sequências do poema, como também um perito na interpretação de poesia. Nesse longo discurso, também, ele se refere à sofística na Lacedemônia como equivalente à filosofia (342b). Essa passagem, como se propõe, fornece algumas chaves de leitura para as relações entre sofística e poesia, por um lado, e entre poesia e filosofia, por outro. Pode-se observar aqui o uso da ironia não só por parte de Sócrates como também por parte de Platão.

Palavras-chave: Sócrates; Platão; ironia; poesia; sofística.

Abstract: In the Protagoras, there is an intriguing passage. After having asked Protagoras to avoid long speeches (334d) because he has allegedly a short memory, Socrates responds to the sophist in a long speech on a poem by Simonides, two sequences of which were quoted by Protagoras. Socrates reveals himself not only as having an excellent memory, since he quotes several further sequences from the poem, but also as an expert in the interpretation of poetry. In this long speech, too, he refers to sophistic in Lacedaemon as paramount to philosophy (342b). This passage, I propose, gives some clues to the relations between sophistic and philosophy, on one hand, and poetry and philosophy, on the other. Here we can see not only Socrates but also Plato assuming an ironic posture.

Keywords: Socrates; Plato; irony; poetry; sophistic. 


\section{Introdução}

A relação entre Platão e a poesia é de fato ambígua, e tem chamado atenção dos comentadores, a começar por Stanley Rosen, que tratou especificamente da questão (ROSEN, 1988). Também abordei o tema, recentemente, ao examinar a comédia nas obras de Aristóteles, Platão e Aristófanes (ROUANET, 2017). Ali, via a "expulsão dos poetas" da cidade ideal de Platão na República como uma espécie de "vingança" de Platão contra os poetas e, especificamente, contra Aristófanes, devido à sua caracterização de Sócrates em As nuvens. Nesta peça, como se sabe, Sócrates é apresentado como um perigoso charlatão, pois nega até mesmo a existência de Zeus. Inclusive, a peça teria contribuído para a condenação de Sócrates, anos depois.

Há pouco, porém, tomei contato com o texto do professor Javier Aguirre, da Universidad del País Vasco, no qual ele defende não um antagonismo de Platão em relação à poesia, mas uma oposição somente à poesia tradicional e de sua época, sendo o próprio filósofo, de certa maneira, o introdutor de uma nova forma de poesia (AGUIRRE, 2013). Tendo a concordar parcialmente com essa tese, e nas próximas páginas procurarei mostrar o motivo.

Para fazê-lo, partirei de uma passagem bastante curiosa do Protágoras e para a qual não se chamou até agora suficientemente atenção. Trata-se da passagem que se estende de $339 a$ a $348 a$. No que segue, farei primeiramente (1) uma exposição do texto, em seus aspectos principais; em seguida (2) farei uma apresentação do longo discurso de Sócrates; por último (3), retomarei a questão da relação de Platão com a poesia, a fim de verificar se a análise do Protágoras contribui para, de alguma forma, alterar a avaliação dessa relação.

\section{Apresentação do diálogo}

O Protágoras é considerado uma obra-prima no que concerne aos primeiros diálogos. Não obstante, no caso de Platão, falar em "obraprima" é algo difícil, pois se torna complicado escolher entre os vários diálogos apenas um que mereça esse título. Além do Protágoras, podese citar, em fases diversas, o Fedro, o Banquete e a República, a título 
de exemplo. Se tivéssemos de escolher um entre toda a obra platônica, permaneceríamos com este último, por ocupar lugar central no projeto platônico, o qual, concordamos, é a paideia (cf. JAEGER, 1995). Então por que consideramos o Protágoras como uma "obra-prima" no que se refere aos primeiros diálogos? Porque, em primeiro lugar, tal texto possui um acabamento artístico que denuncia os dotes dramáticos do autor. ${ }^{1} \mathrm{De}$ maneira resumida, eis os pontos principais do diálogo:

Preâmbulo: Sócrates encontra um amigo, não identificado, que lhe pergunta de onde ele vem, fazendo troça de Sócrates, aludindo a seu interesse por jovens, e especialmente por Alcibíades, então seu favorito:

O AMIGO - De onde vens, Sócrates? Sem dúvida da caça à beleza de Alcibíades? Eu o vi justamente antes de ontem e, é verdade, considerei que ainda é um belo homem. Mas um homem, Sócrates, que fique entre nós, já com toda essa barba que lhe cresce no rosto! (Prot. 309a.) ${ }^{2}$

A alusão ao crescimento da barba indica que já não é mais apropriado, em se tratado de homem feito, continuar a cultuar o gênero de relações homoeróticas, que são toleradas no caso de se tratar de jovens.

Diante disso, Sócrates responde que não, que acabava de encontrar alguém mais belo do que Alcibíades, belo pelo saber (cf. Cármides, 154e e passim). Trata-se de um estrangeiro, de Abdera, a

\footnotetext{
${ }^{1}$ Segundo Diógenes Laércio, Platão teria escrito comédias na juventude, mas as teria queimado após tomar contato com Sócrates e a nova maneira de pensar deste último. Quanto ao gênero "prosa filosófica", Platão parece ter sido o introdutor dessa modalidade (cf. PERINE, 2013). Em sua "Notícia sobre o Protágoras", E. Chambry se refere ao diálogo como uma "comédia filosófica", e também alude aos dons teatrais de Platão, e diz que "a admiração exclusiva que lhe inspirou Sócrates talvez tenha custado à Grécia um grande poeta cômico" (CHAMBRY, in PLATON, s/d, p. 1). Isso poderia ser verdade se Platão houvesse se revelado um filósofo medíocre, o que está longe de ser o caso. Pelo contrário, pode-se dizer que, como poeta cômico, Platão foi um prodigioso filósofo! Sobre a visão de Platão por Diógenes, cf. Marques, 2013.

${ }^{2}$ Sigo a tradução de Frédérique Ildefonse, na edição de Luc Brisson (PLATON, 2011), comparada com a tradução de E. Chambry (PLATON, s/d) e o original grego

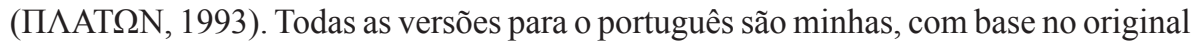
e em traduções modernas, exceto quando indicado em contrário.
} 
saber, Protágoras (Prot. 139c-d). Em seguida, Sócrates passa a narrar os acontecimentos do dia.

Hipócrates, o jovem (homônimo do médico), procura Sócrates, logo pela manhã, para informar que Protágoras chegara à cidade, estando hospedado na casa de Cálias. Pede a Sócrates que o apresente, pois deseja tomar aulas com ele (310b-311a).

Como ainda é cedo, ambos passeiam pelo pátio, e Sócrates aproveita para perguntar ao jovem o que ele deseja aprender com o sofista, e se deseja, também, tornar-se um sofista. Hipócrates responde, enrubescendo, que não, embora essa seja a consequência lógica da série de perguntas que Sócrates lhe colocara. A ocupação de sofista não é ainda bem aceita aos olhos dos gregos, ao que parece:

SÓCRATES - Se colocassem ainda esta questão: Mas tu, o que desejas te tornar, procurando Protágoras? Ele me respondeu, enrubescendo, pois já estava bastante claro para que se pudesse bem vê-lo: "Se formos consequentes, quero evidentemente me tornar um sofista." - Em nome dos deuses, eu lhe disse, não enrubescerias de te passar por sofista diante dos gregos? - Sim, por Zeus, Sócrates, se devo dizer o que penso. (312a)

Os dois se dirigem, então, para a casa de Cálias, onde está hospedado Protágoras, acompanhado de vários sofistas e de outros personagens: Hípias, Pródico de Ceos, Pausânias, Alcibíades e Crítias (315a-316a). A cena que encontra ao entrar é digna de uma comédia, e é fácil imaginar sua representação sobre um palco:

Ao entrar, encontramos Protágoras, que passeava no pórtico, acompanhado de um lado de Cálias, filho de Hipônicos, de seu irmão por parte de mãe, Paralos, filho de Péricles, e de Cármides, filho de Gláucon; do outro lado, do outro filho de Péricles, Xantipo, de Filipides, filho de Filomelos, de Antimoiros de Mendes, o mais renomado dos discípulos de Protágoras, que estuda para seguir a ocupação de sofista; por trás deles, esforçando-se por escutar, caminhava uma tropa de pessoas nas quais dominavam evidentemente os 
estrangeiros que Protágoras arrasta de cada cidade pela qual passa: ele os encanta com sua voz, como Orfeu e, enfeitiçados por essa voz mágica, seguem os seus passos; havia também, no coro, pessoas daqui [de Atenas]. Ao ver esse coro, diverti-me em observar com que deferência eles evitavam atrapalhar Protágoras, que se encontrava diante deles; todas as vezes que ele virava com sua companhia, todo o séquito de ouvintes se afastava à direita e à esquerda numa ordem perfeita e, organizando-se em círculo, voltava a se colocar atrás dele com uma concatenação admirável. $(315 a-b)$

O resto da descrição também impressiona pelo colorido da cena. Que se trata de um quadro fica claro no momento em que Sócrates se dirige ao sofista: "Quanto a nós, após havermos passado pela porta, passamos alguns instantes a contemplar esse quadro; depois, avançamos na direção de Protágoras e eu lhe disse: 'És tu que buscamos, Protágoras, Hipócrates que aqui está e eu.'” (316b)

$\mathrm{O}$ assunto inicial da conversa é aquilo que Protágoras pode fazer por Hipócrates, jovem de família rica e influente, e que deseja "ocupar um lugar ilustre na pólis" (316c). Protágoras se assume como sofista, embora saiba que existe muita prevenção contra essa ocupação. Outrora, diz ele, os sofistas se mascaravam de poetas, como foi o caso de Homero, Hesíodo e Simônides. Hoje, não é preciso assumir esse disfarce, e declara: "confesso que sou sofista e que educo os homens" (317b).

Percebendo a vaidade do sofista, e que ele quer se exibir para seus pares e para os circunstantes, Sócrates propõe que se chame os demais e se forme uma roda. E todos concordam. O cenário está montado. Sócrates volta a colocar a questão: que benefício receberá Hipócrates ao se colocar na "escola" de Protágoras e gozar de sua companhia? (318a).

Não é nossa intenção, aqui, reproduzir toda a sequência do diálogo, o que já foi feito muitas vezes (p. ex., JAEGER, 1995, p.621 e ss.). Importa chamar atenção para seus aspectos essenciais. É consenso entre os comentadores que o tema central do diálogo é a possibilidade de se ensinar a virtude. O que se entende por virtude, porém, não é claro, pois as posições de Sócrates e Protágoras variam a respeito, ocorrendo 
uma espécie de inversão das posições de ambos. Inicialmente, Sócrates sustentaria que a virtude não pode ser ensinada, e Protágoras defenderia a posição contrária. Ao final do diálogo, porém, as posições se invertem. $\mathrm{O}$ que nos parece claro é que a maior parte das divergências ocorre porque o sofista e o filósofo entendem por virtude coisas diferentes: o primeiro defenderia a noção de virtude (areté) como excelência em algo, enquanto o segundo, que se trata de virtude no sentido moral. É o que mostra Werner Jaeger, ao comentar a passagem de 329d: "O problema parece agora complicar-se por ele [Protágoras] apresentar a sabedoria ( бoధía) como mais uma parte da virtude, acrescentando, portanto, às virtudes morais uma virtude ou areté intelectual" (p. 634).

Sócrates parece comprazer-se, também, em mudar constantemente de terreno, como se estivesse a esgrimir um adversário perigoso. Utilizar a mesma palavra em dois sentidos diferentes é uma das características do discurso sofístico; trata-se da falácia de ambiguidade, ou anfibologia (Ref. sof. 166 ) : quando se utiliza um termo em mais de uma acepção. É o caso de "virtude". Sócrates parece se utilizar, aqui, desse recurso sofístico.

\section{Protágoras 339a-348a}

O trecho mais amplo no qual se insere o longo discurso de Sócrates se inicia em $339 a$ e constitui uma retomada da discussão, após sua interrupção em 334d, quando Protágoras termina seu discurso e Sócrates diz possuir "memória fraca" e se perder em longos discursos. Protágoras se recusa a continuar a discussão, e Sócrates se prepara para partir, quando intervêm os demais personagens presentes: Alcibíades, Pródicos e Hípias, entre outros. Diz Sócrates:

Ocorre, Protágoras, que possuo memória fraca, e se alguém me dirige um longo discurso acabo por esquecer aquilo de que ele fala. Se eu fosse um pouco surdo, pensarias que seria preciso falar mais alto comigo do que com os outros, se quisesses discutir comigo; pois bem, da mesma maneira, uma vez que te deparastes com alguém que possui memória fraca, condensa tuas respostas e as dê mais curtas, se queres que eu te siga. (Prot. 334d) 
Como se verá, a alegação de Sócrates de que possui "memória fraca" é falsa, uma vez que ele próprio, entre $342 b$ e $347 a$, pronunciará um longuíssimo discurso, no qual analisa de maneira minuciosa o poema de Simônides, que ele conhecia de cor, tendo-o já estudado anteriormente. ${ }^{3}$ Segundo o professor Michelsen, não é tanto a extensão do discurso pronunciado por Protágoras como seu conteúdo o que perturba Sócrates: "A resposta de Sócrates é bizarra, e totalmente ininteligível até que se perceba que não é sua extensão, mas seu conteúdo que o ofende." (MICHELSEN, 1991, p. 243)

A estratégia de Sócrates tem um problema, pois ela permite que Protágoras mude o terreno da discussão para a poesia, ponto central da paidéia da época, e apropriada pelos sofistas. É o que pensa também Jaeger, como se pode observar a seguir:

A tensão artística do diálogo baseia-se em grande parte na tenaz consequência com que Sócrates se fixa nesta meta [a saber, examinar as virtudes e a relação entre elas] e se nega a sair do terreno da análise dialética. Concede a Protágoras, no entanto, um largo fôlego, de que este se aproveita para desviar a conversa para outro terreno, o da explicação poética, uma das formas essenciais da paidéia sofística. (JAEGER, 1995, p. 636)

Como se disse, depois da interrupção e da intervenção dos presentes, Protágoras e Sócrates concordam em retomar a discussão. Desta vez, Protágoras inicia, colocando uma questão a Sócrates com base nos poemas de Simônides: ${ }^{4}$

A meu ver, Sócrates (...), a parte mais importante da educação de um homem consiste em ser competente em poesia, ou seja, ser capaz de compreender, na produção dos poetas, aquelas que são corretamente feitas e aquelas que

\footnotetext{
${ }^{3}$ Diz Protágoras: “'Conheces essa ode, ou devo recitá-la por inteiro?' Disse eu então: 'É inútil! Eu a conheço, e ocorre que me dediquei bastante a estudá-la.'” (339b)

${ }^{4}$ Segundo a edição de Luc Brisson, o diálogo Protágoras é a única fonte para essa ode de Simônides. (Cf. PLATON, [2008] 2011, p. 1461, n. 1 a 339b) Simônides de Ceos teria vivido entre c. de 556 e 468 a.C.
} 
não o são, em saber distingui-los e em saber explicar seus julgamentos, caso lhe seja perguntado. Minhas questões, é claro, dirão respeito ao mesmo tema que discutíamos, tu e eu, agora há pouco, sobre a virtude, mas transportado para o terreno da poesia: esta será a única diferença. (339a)

Sócrates aceita a transposição para o terreno que o adversário lhe propõe, mostrando-se ser "competente em poesia" e, portanto, um homem educado. Não o faz, porém, sem um pequeno desvio, no qual introduz Pródicos de Ceos na discussão, provavelmente para ganhar tempo para pensar na resposta. ${ }^{5}$ Mas antes, vejamos os dois fragmentos da poesia, e a interpretação que lhes dá Protágoras.

Sem dúvida, tornar-se realmente um homem de valor é difícil, bem tornado das mãos, dos pés e do espírito, moldado sem

[defeito. ${ }^{6}(339 b)$

E, logo em seguida, acrescenta os seguintes versos:

Assim como, a meu ouvido, não soa justa a fala de Pítacos, todavia pronunciada por um sábio mortal; é difícil, diz ele, [ser valoroso. $(339 c)$

Protágoras vê contradição entre esses versos, pois, segundo ele, o poeta se contradiz quando afirma que "tornar-se um homem de valor é difícil" e, logo depois, critica a fala de Pítacos, o qual diria que “é difícil ser valoroso". É nesse ponto que Sócrates se considera, de certo modo, nocauteado ("como se eu acabasse de receber um soco de um bom pugilista" [339e]). Sócrates aponta que "tornar-se valoroso" e "ser valoroso" não são a mesma coisa, ponto que ele demonstrará mais à frente.

Protágoras não aceita a resposta, e Sócrates tem que se explicar melhor. (340b-340e) Na sequência, porém, Sócrates parece brincar com as palavras, em uma espécie de paródia do procedimento dos sofistas, e talvez do próprio Pródicos, a quem toma provisoriamente por interlocutor.

\footnotetext{
5 “ (...) depois, para te dizer a verdade, a fim de ganhar tempo para refletir no que dissera o poeta, volto-me para Pródicos, e o interpelo (...)”. (339e)

${ }^{6}$ Sigo a tradução francesa, com alterações.
} 
Servindo-se do fato de que, aparentemente, Simônides e Pródicos provêm do mesmo lugar, faz um elogio irônico do sofista, declarando-se seu "discípulo", algo que denota a intenção irônica, como ficara claro no Eutífron, no qual adota o mesmo procedimento. (Eut. 5c-d) Assim, ao passar-se por discípulo de Pródicos, pergunta a este: "Pródicos, o que Simônides entendia por difícil?" E o sofista responde: “Um mal". (341c) A definição é evidentemente fraca, e facilitará sua rejeição por Protágoras. De fato, é como se Sócrates quisesse ganhar tempo, aproveitando para ridicularizar outro sofista. ${ }^{7}$ Vale a pena reproduzir a réplica de Protágoras, com a qual concorda Sócrates, colocando-se novamente no mesmo patamar que o primeiro:

Disse Protágoras então: "Não é isto Pródicos, longe disso. Quanto a mim, sei de maneira pertinente que Simônides empregava o termo "difícil" como nós o empregamos, para designar não um mal, mas o que não é fácil, o que só se obtém ao custo de muitos esforços. - Mas eu também, Protágoras, disse eu, acredito que é o que Simônides quer dizer, e que Pródicos o sabe muito bem, mas que ele brinca e quer te pôr à prova para ver se serás capaz de defender tua tese; quanto ao fato de que Simônides não entende "difícil" no sentido de "mau", a expressão que ele emprega logo depois fornece sua prova manifesta. Ele diz, com efeito: Só um Deus pode ter esse privilégio. (341d-e)

Sócrates então se propõe a discorrer sobre o poema, para mostrar-se "competente em poesia", como dizia Protágoras, ou então ouvir novamente Protágoras. Este e a audiência concordam em ouvir Sócrates. Aí se inicia um longo discurso, em contradição com o que dissera (334d) sobre ter fraca memória e ser incapaz de seguir um longo discurso. Parece, pois, que não o faz por falta de capacidade, mas por preferir outro método.

\footnotetext{
${ }^{7}$ Sobre Sócrates como sofista, cf. Rouanet, 2015.
} 


\section{O longo discurso de Sócrates (Prot. 342b-347a)}

O discurso que Sócrates faz, agora, estende-se de $342 b$ a $347 a$ e se inicia com um elogio dos costumes da Lacedemônia (Esparta). Diz que é um dos lugares que possui maior quantidade de sofistas - e o uso desse termo, neste caso, não parece ser pejorativo, sendo equivalente ao de homens dotados de sabedoria, "sapientes". Assim:

É em Creta e na Lacedemônia, com efeito, mais do que em qualquer outra parte da Grécia, que o desejo pelo saber existe há mais tempo e é o mais difundido, e é igualmente nesse lugar da terra que há o maior número de sofistas (...). $(342 b)$.

Os espartanos, no entanto, fingiriam ignorância e deixariam que os habitantes das outras cidades pensassem que sua superioridade se deveria unicamente a suas habilidades guerreiras e a seu treinamento para a luta. No entanto, prossegue Sócrates,

quando eles, os lacedemônios, desejam se entreter livremente com seus próprios sofistas e se cansam de frequentá-los às escondidas, expulsam esses laconizantes [admiradores e imitadores dos espartanos] e todos os estrangeiros, quaisquer que sejam, que se encontrem entre eles, a fim de poder frequentar os sofistas sem que os estrangeiros o saibam, e não permitem a nenhum de seus próprios jovens irem a outras cidades - da mesma maneira que os cretenses, aliás - por temer que eles esqueçam o que lhes é ensinado. E nessas cidades, não são somente os homens que têm a educação em alta conta, também as mulheres o fazem. $(342 c-d)$

A proverbial secura e brevidade de seus ditos - afinal, é o que se entende por "laconismo", em nossos dias - se deveria, na visão de Sócrates, ao conhecimento que possuem, devido a terem debatido extensamente com seus sofistas e entre si. Pelo contrário, e esta parece ser a visão de Sócrates: 
(...) agora como antes, há pessoas que compreendem que laconizar consiste bem mais no amor pelo saber do que no amor pela ginástica, porque eles sabem que é preciso ter recebido uma educação perfeita para ser capaz de pronunciar semelhantes fórmulas. (342e-343a)

Sabe-se que um dos motivos ocultos que podem ter levado à condenação de Sócrates foram suas críticas à democracia e sua tendência "laconizante" (cf. STONE, 2005). Sócrates cita em apoio a suas teses sete sábios que seriam herdeiros dessa forma de se expressar, ou eles mesmos provenientes da Lacedemônia: Tales de Mileto, Pítacos de Mitilene, Bias de Priene, Sólon, Cleóbulo de Lindos, Mison de Quené e Quílon da Lacedemônia. Teriam sido eles a escrever, no templo de Apolo em Delphi, as frases: "Conhece a ti mesmo" e "Nada em excesso". (343a- $b$ )

$\mathrm{O}$ desvio é feito para mostrar que Pítacos era partidário dessa maneira de se expressar, e teria sido por rivalidade que Simônides, desejoso de ganhar reputação como sábio, ataca o dito lacônico do primeiro, que "é difícil ser valoroso" (343c). E Sócrates passa a analisar o poema de Simônides, não só demonstrando conhecê-lo, como se mostrando "competente em poesia", ao analisá-lo do ponto de vista da forma e do conteúdo. Em determinado momento, efetua uma paráfrase de parte do poema, nestes termos:

(...) tornar-se sem dúvida um homem de valor é realmente difícil, mas é possível tornar-se um por certo tempo; quando se chegou a isso, permanecer nesse estado, porém, e "ser" um homem de valor, como dizes, Pítacos, não é possível nem humano, e somente um Deus pode ter esse privilégio. (344c)

Pode-se aproximar essa passagem da dificuldade de se alcançar as ideias, em especial, a ideia do Bem, a qual somente os bem-aventurados vislumbram, somente, por um momento, para logo em seguida perdê-la de vista (cf. Fedro, 248a e passim). Somente um Deus pode permanecer nesse estado "perfeito"; os humanos não podem suportá-lo por muito tempo, e logo são "rebaixados", como diz Simônides: "Mas não ser mau não é possível ao homem,/ que uma desgraça sem apelo rebaixa". (Prot. 344c) 
Sócrates cita - em apoio à sua interpretação, de que somente um homem de valor por ser rebaixado "sem apelo" - uma estrofe de outro poeta, não identificado: "Pois o homem de valor tanto pode ser covarde como valoroso". (344d) O covarde não pode se tornar covarde, pois já o é; então somente o homem de valor pode se tornar covarde, se "uma desgraça sem apelo rebaixa”. Então, segundo a interpretação de Sócrates, tornar-se homem de valor é difícil, quanto a ser homem de valor, isto é impossível! (344e): "Pois no sucesso todo homem é de valor,/ e todo homem é mau no fracasso". (ibidem)

Sócrates reforça sua defesa do conhecimento como aquilo que dá "valor" a um homem. Por exemplo: "O que é sucesso no domínio da escrita, e o que faz o valor de um homem no domínio da escrita?" (345a) Aqui, se esperaria um desenvolvimento sobre a escrita enquanto domínio literário da língua, já que Platão é um de seus mestres, mas Sócrates se limita a dizer: "É evidente que é seu conhecimento do alfabeto". O mesmo se aplica em relação ao médico. Só o médico pode cometer erros e ainda assim ser considerado um médico; quanto a nós, que somos leigos, um erro não faz de nós "médicos, arquitetos ou qualquer coisa de análogo". (345b) Dessa forma, "o fracasso nada mais é do que a privação da ciência". (ibidem) Chegamos aí a um ponto crucial da concepção de ciência de Platão neste momento de sua obra: a identificação do bem com o conhecimento, e do mal com a ignorância, ou ausência de saber. Essa tese, como se sabe, só será posta em questão no Sofista, quando Platão comete um assassinato simbólico de seu pai Parmênides. (Sof., 241d) De qualquer modo, na passagem que ora examinamos, o que Sócrates deseja provar é que é possível ir do ser ao não ser e, portanto, que só é possível ao homem de valor tornar-se mau, uma vez que o homem sem valor, e sem conhecimento, já é mau e não pode tornar-se mau. Não é possível, então, ser um homem de valor por tempo indefinido, mas que os melhores são aqueles que permanecem mais tempo nesse estado (345c). E dando provas de sua memória prodigiosa, Sócrates continua citando o poema de Simônides: 
Por esse motivo, sem procurar atingir o que não pode ocorrer, jamais por uma vazia esperança que não pode chegar a bom termo [eu arriscaria minha parte da vida por um homem que não se presta de modo algum a crítica, entre [nós todos que tomamos posse do fruto da vasta terra; e se o encontrar eu vos anunciarei; (345c)

E em seguida:

Eu louvo e amo

todos aqueles, que de bom grado, não cometem nada de feio, quanto à necessidade, nem mesmo os deuses a combatem... (345d) Basta-me de um homem que ele não seja nem mau, nem intratável, mas conhecendo a justiça que serve à cidade; de um homem que seja sadio; a este eu não criticarei; com efeito, a raça dos tolos é infinita. Tudo é belo, aonde o feio não foi se meter. $(346 c)^{8}$

Gostaria de reiterar duas coisas. Em primeiro lugar, não é por incapacidade que Sócrates não aprecia longos discursos, podendo pronunciá-lo em ocasiões - como no Fedro, na passagem citada, ou no Fédon, no longo relato sobre o destino das almas (Fédon 108 a e ss.), para tomar apenas dois exemplos -, mas que, na maior parte dos casos, prefere não fazê-lo, por preferir outro método (maiêutica, dialética). Em segundo, tendo demonstrado que é "competente em poesia", considera esse gênero de disputa como fútil, no entanto, e próprio a banquetes regados à bebida (cf. O banquete), e não a discussões sérias, como é esta a que ele se entrega com Protágoras.

Assim, terminado o discurso, Sócrates se volta para Protágoras, instando-o a retomar a discussão "séria": “... se ele [Protágoras] assim o desejar, deixemos de lado os versos e os poemas. Protágoras, eu gostaria de retomar o tema sobre o qual te interroguei de início [a virtude]”. (347c)

${ }^{8}$ Tradução livre, segundo tradução francesa de Frédéric Ildefonse. (In: PLATON, Oeuvres complètes, org. Luc Brisson, op. cit., p. 1466 e ss). 
Desse modo, façamos como ele, e retomemos o curso da exposição.

\section{A querela entre poesia e filosofia e a intenção de Sócrates}

Há, como se sabe, antiga querela entre a poesia e a filosofia, que é mencionada por Platão: “(...) tem havido uma longa e contínua disputa entre filosofia e poesia”. (Rep. X, 607b) ${ }^{9}$ Nesse sentido, o Protágoras, de certo modo, é um capítulo dessa querela, a qual pode ser rastreada em diversos diálogos de Platão - a Apologia, o Íon, a República, o Banquete e as Leis, por exemplo. Mas o que se deve pensar a respeito dessa passagem do Protágoras, na qual Sócrates se mostra "competente em poesia", não só demonstrando conhecimento do poema citado, de Simônides, como efetuando uma análise literária "em regra" do poema? Dá a entender, inclusive, que essa análise poderia ser mais extensa, se necessário fosse:

Com efeito, é possível demostrar, a partir de cada detalhe da ode, que ela é bem feita: é uma obra cuidadosa e cheia de graça. Mas seria muito longo analisá-la assim, ponto por ponto; contentemo-nos, portanto, em considerá-la em suas grandes linhas e em sua intenção de conjunto (...). (344b)

Apesar de conhecer poesia e dominar a arte de análise literária, Sócrates não dá tanto valor a ela, considerando-a objeto de discussão de pessoas fúteis, para seu entretenimento em festas regadas à bebida, como ele diz ao final de seu discurso:

De fato, as discussões sobre a poesia me parecem efetivamente semelhantes a banquetes entre homens medíocres e grosseiros: quando bebem juntos, são incapazes, por falta de educação, de encontrar em si mesmos, por meio de suas próprias vozes, seus próprios discursos, com o que se entreter mutuamente; aumentam os preços das tocadoras de flauta, uma vez que pagam muito caro por uma voz estrangeira, a das flautas, e só se entretêm entre si pela mediação dessa voz. $(347 c-d)$

\footnotetext{
${ }^{9}$ É exatamente daí que parte Rosen (1988, p. 1, 2 e ss.).
} 
Já entre homens, sérios, estes dispensam esses recursos, "sendo capazes de encontrar em si mesmos com o que se entreter entre si" (idem). O Banquete, obviamente, seria um exemplo desse segundo tipo de reunião, como fica claro em 176d, quando Erixímaco, atendendo à disposição dos presentes, dispensa a musicista, e acrescenta: "Quanto a nós, empregaremos o tempo que durará a reunião de hoje a pronunciar discursos."

Então, ocupar-se de poemas, pelo menos na visão de Sócrates, é coisa fútil, sendo menos importante do que se ocupar da própria alma ("conhece-te a mim mesmo") e em estudar aquilo que é necessário para fazer dos homens melhores cidadãos. Daí sua exortação a Protágoras para que, juntos, retomem a discussão séria, aquela sobre a virtude. Este é o tema que não se deve perder de vista, em todo o diálogo. Isso parece decorrer das palavras finais de Sócrates no Protágoras, quando enfatiza a centralidade da discussão sobre a virtude, e se ela pode ou não ser ensinada. Afinal, essa parece ser a principal questão opondo sofistas e filósofos.

$\mathrm{Na}$ verdade, disse eu, se te ponho todas essas questões, é unicamente porque desejo examinar o que é da virtude, e o que pode ser ela, a virtude. Pois eu sei, é somente se esse ponto for resolvido que teremos clareza sobre aquilo que eu e tu mantivemos um longo discurso cada um, eu para dizer que a virtude não podia ser ensinada, e tu para dizeres que ela podia ser ensinada. ${ }^{10}$

Assim, não podemos nos deixar desviar pelo longo discurso de Sócrates sobre a poesia, em especial, sua análise da ode de Simônides, que mostravam, como já exposto aqui, que Sócrates podia analisar poesia, se assim o desejasse, e que a poesia não é o assunto que deve ocupar pessoas "sérias", isto é, que têm como centro de sua preocupação o bem do cidadão e o bem da pólis.

${ }^{10}$ Prot. 361a. Na versão de Jaeger, a centralidade da virtude para a discussão fica ainda mais evidente: "Peço que tudo isto não se examine com outro fim que não seja o de inquirir o que é a virtude e qual a sua essência, pois sei que, uma vez esclarecido isto, ficará esclarecido também aquilo sobre que ambos estivemos conversando tão longamente, eu sustentando que se não pode ensinar a virtude e tu defendendo que ela pode ser ensinada." (JAEGER, 1995, p. 643, itálicos do autor). 


\section{Conclusão}

Procurou-se mostrar que o Protágoras tem como um de seus temas a querela entre a poesia e a filosofia, que aparece em outros diálogos de Platão, notadamente no Íon, no Banquete e na República, entre outros. Embora não se possa dizer que seja seu tema principal, esse debate ocupa no Protágoras lugar de destaque, dada a longa análise do poema de Simônides por parte de Sócrates, em resposta ao questionamento do sofista. Posteriormente, como se mostrou também, esse tipo de análise é rejeitada como "fútill", não devendo ser a ocupação de homens sérios, com intenção filosófica. Estes devem rejeitar recursos externos, como flautas, danças, divertimentos utilizados por aqueles que não conseguem se ocupar com os próprios discursos.

O que parece estar em jogo aqui, então, é o questionamento da paideia da época, baseada na memorização e recitação de poemas, como se os poetas fossem sábios, cujas palavras devem ser decoradas e seus ditos, e os feitos de seus personagens, tomados como modelo. Sócrates tem dificuldade em provar esse ponto, pois possui diante de si um adversário à altura. Protágoras é pensador refinado, e embora ganhe a vida percorrendo a Grécia e falando para quem se dispuser a pagar para ouvi-lo - atividade a qual, em nossos dias, pode ser considerada normal e pouco reprovável -, não é um charlatão ou escravo de sua própria vaidade, sendo capaz de debater de igual para igual com Sócrates. Protágoras não é um ingênuo como Eutífron, Íon ou mesmo Hípias - está na categoria dos "mestres da sofística", ao lado de Górgias e de alguns poucos mais; não se trata de um mero erista.

É por esse motivo, talvez, que as posições defendidas por ambos no diálogo se invertem: Platão não é um dogmático, e sabe que suas posições não estão a salvo de críticas, e quem sabe é o adversário quem está com a razão? A discussão não termina, no Protágoras, pelo exame da poesia. Protágoras fica em silêncio, após esse longo discurso, mostrandose resistente a continuar, e só aceitando fazê-lo, mais uma vez, após as intervenções de Alcibíades e Cálias (548b-c).

O incentivo de Sócrates para que Protágoras retome a discussão é bastante amigável, e não irônico: evidentemente, Sócrates está se 
dirigindo a um igual, alguém a quem respeita. Sendo assim, lança mão de outro poeta, Homero, para ressaltar a importância de examinarem a questão juntos: "Quando dois homens caminham juntos, um pode ver antes do outro." (348d - Ilíada X, 224-225) Em outros termos, não se pensa sozinho, é preciso procurar outra pessoa com quem compartilhar a tarefa de tentar estabelecer o que se pensa (ibidem). O processo de conhecimento não é individual, mas uma construção coletiva, ou exige pelo menos duas pessoas para que se realize. Novamente, conforme se pode ver, Sócrates não é irônico quando elogia Protágoras:

(...) prefiro, por meu lado, discutir contigo mais do que com qualquer outro, pois penso que és tu quem estás em melhor condição para examinar todos os assuntos que convêm ser considerados por pessoas de qualidade, e mais precisamente, a questão da virtude. (348e)

Assim mesmo, pode-se ver algum excesso nesse elogio de Protágoras por Sócrates. Este reconhece a vaidade do sofista e quer cativálo por essa via. Uma vez que Protágoras tem a coragem de se assumir como sofista e é capaz de ensinar a outros, Sócrates deseja continuar se entretendo com ele.

Dessa maneira, o exame da continuação do diálogo nos afastaria do tema a que nos propusemos, a saber, a análise do "longo discurso" de Sócrates. Sendo assim, ao que me propus, acredito ter explicado algumas das razões para a adoção dessa estratégia por parte de Sócrates: 1) mostrar que era "competente" em poesia, e que poderia discorrer na maneira habitual à cultura da época, se assim o desejasse; 2) mostrar que, por mais profunda que seja a análise literária, esta não é equivalente a uma discussão filosófica em termos de profundidade e seriedade; 3) defender que a verdadeira paideia não deveria basear-se na poesia, mas na busca da sabedoria, por meio de argumentos racionais em discussões entre homens sérios.

Em suma, quanto à aparente inversão de posições entre Protágoras e Sócrates no decorrer do diálogo, esta pode se dever a: 1) ausência de dogmatismo em Platão; este estaria disposto a mudar de posição, caso fosse convencido no curso da argumentação; 2) a sugestão de que, no 
fundo, Sócrates adota estratégias sofísticas, como utilizar um mesmo nome em sentidos diferentes; Sócrates seria, ainda, um sofista, mesmo que do tipo mais elevado.

Uma possível continuação desta leitura do Protágoras envolveria o exame da parte final do Protágoras, bem como do diálogo Górgias, diálogo este que, sob muitos aspectos, pode ser considerado "irmão" do primeiro. Ali, também, Sócrates encontra adversários à altura, a saber, o próprio Górgias, que pouco participa da discussão, e Cálicles, personagem misterioso e que é um dos poucos a não abaixar a cabeça diante de Sócrates, chegando até mesmo, sob determinado ponto de vista, a vencer a discussão.

\section{Referências}

AGUIRRE, J. Platón y el conflito entre la vieja y la nueva poesía, Convivium, São Paulo, v. 26, p. 5-28, 2013.

JAEGER, W. Paidéia. Trad. Artur M. Parreira. São Paulo: Martins Fontes, 1995.

MARQUES, M. Platão, personagem de Laércio. In: LEÃO, D.; CORNELli, G.; PEIXOTO, M. C. (Org.). Dos homens e suas ideias - Estudos sobre as vidas de Diógenes Laércio. Coimbra: Imprensa da Universidade de Coimbra, 2013, p. 109-124. Disponível em: <https:// digitalis-dsp.uc.pt/bitstream/10316.2/34708/1/Doshomens_artigo8. pdf?ln=pt-pt $>$. Acesso em: 10 out. 2017.

MICHELSEN, J. M. Socrates and the unity of APETH. In: BOUDORIS, K. J. (Ed.). The Philosophy of Socrates. Atenas: International Center for Greek Philosophy and Culture, 1991. p. 237-243.

PLATON, Oeuvres complètes. Org. Luc Brisson. Paris: Flammarion, [2008] 2011.

PLATON, Oeuvres complètes. Trad. E. Chambry. Paris: Garnier, [s/d.]. V. II.

П $\Lambda$ AT $\Omega \mathrm{N}, \Pi \mathrm{P} \Omega T A \Gamma O P A \Sigma$, Texto em grego antigo com versão em grego moderno. Atenas, GR: Kaktos, 1993. 
ROSEN, S. The Quarrel between Philosophy and Poetry. Studies in Ancient Thought. New York; London: Routledge, 1988.

ROUANET, L. P. Some remarks about comedy in Aristotle, Aristophanes, and Plato. SFENDONI-MENTZOU, Demetra (Org.). Proceedings of the World Congress "Aristotle 2400 Years". Tessalonica, GR: Aristotelic University of Thessalonica, 2017. (no prelo).

ROUANET, L. P. Socrates, the greatets sophist? In: HANNAH, Patricia (Org.). An anthology of philosophical studies, $\mathrm{n}^{\circ}$. 9. Atenas, GR: Athens Institute for Education and Research, 2015. p. 111-19.

STONE, I. F. O julgamento de Sócrates. Trad. Paulo Henriques Brito. São Paulo: Cia. das Letras, 2005.

Recebido em 15 de setembro de 2017. Aprovado em 21 de novembro de 2017. 